JOURNAL OF MIDWIFERY CARE :

VOL. 01 NO. 01, DESEMBER 2020

DOI: $\underline{10.34305 / j m c . v 1 i 1.179}$
Ciptaan disebarluaskan di bawah

Lisensi Creative Commons Atribusi-

NonKomersial-BerbagiSerupa 4.0

\title{
GAMBARAN PEMERIKSAAN HIV/AIDS PADA IBU HAMIL BERDASARKAN KARAKTERISTIK DI PUSKESMAS BANJAR I KOTA BANJAR
}

\author{
${ }^{1}$ Hana Eldiani, ${ }^{2}$ Russiska, ${ }^{3}$ Merissa Laora Heryanto \\ ${ }^{1,2,3}$ Sekolah Tinggi Ilmu Kesehatan Kuningan
}

hanaeldiani15@gmail.com

\begin{abstract}
Abstrak
Kasus HIV/AIDS di dunia mencapai 36,7 juta penderita pada tahun 2015, di Indonesia dalam setiap 25 menit terdapat satu orang terinfeksi HIV/AIDS, sedangkan di Kota Banjar ada 300 orang yang terjangkit HIV/AIDS tahun 2019. Data kementrian kesehatan menunjukkan dari $21.103 \mathrm{ibu}$ hamil yang menjalani tes HIV/AIDS sebanyak 534 (2.5\%) diantaranya positif terinfeksi HIV/AIDS. Tujuan penelitian ini adalah mengetahui gambaran pemeriksaan HIV/AIDS pada ibu hamil berdasarkan karakteristik di Puskesmas Banjar I Kota Banjar Tahun 2019. Jenis penelitian deskriptif kuantitatif menggunakan rancangan cross-sectional. Responden berjumlah 243 responden menggunakan teknik total sampling. Instrumen berupa lembar checklist. Analisis data menggunakan univariat. Hasil analisis dari 243 responden sebagian besar tidak dilakukan pemeriksaan HIV/AIDS sebanyak 24 responden (10\%), sebagian besar usia reproduksi sehat tidak dilakukan pemeriksaan sebanyak 21 responden (9.5\%), sebagian besar pendidikan rendah tidak dilakukan pemeriksaan sebanyak 13 responden (22.4\%), sebagian besar pekerjaan bekerja tidak dilakukan pemeriksaan sebanyak 4 responden (11.8\%), dan sebagian besar paritas multipara tidak dilakukan pemeriksaan sebanyak 22 responden (12.71\%). Kesimpulan penelitian ini yang tidak melakukan pemeriksaan HIV/AIDS sebagian besar pada usia reproduksi sehat, pendidikan rendah, bekerja, dan paritas multipara. Disarankan kepada bidan agar melakukan kunjungan rumah khususnya pada ibu hamil yang tidak melakukan pemeriksaan HIV/AIDS.
\end{abstract}

Kata Kunci $\quad$ : Ibu Hamil, HIV/AIDS, Karakteristik

\section{Pendahuluan}

Penyakit HIV/AIDS telah menjadi epidemi yang berkembang pesat di seluruh dunia. Berdasarkan data WHO (2015), penemuan kasus orang yang hidup dengan HIV/AIDS pada tahun 2015 mencapai 36,7 
JOURNAL OF MIDWIFERY CARE :

VOL. 01 NO. 01, DESEMBER 2020

DOI: $10.34305 /$ jmc.v1i1.179
Ciptaan disebarluaskan di bawah Lisensi Creative Commons AtribusiNonKomersial-BerbagiSerupa 4.0

(Ditjen PP dan PL Kemenkes RI, 2017). Data kementrian kesehatan menunjukkan dari 21.103 ibu hamil yang menjalani tes HIV/AIDS sebanyak $534 \quad(2.5 \%)$ diantaranya positif terinfeksi HIV/AIDS.

Upaya pencegahan penularan HIV/AIDS dari ibu ke anak bisa ditangani dengan pelayanan antenatal yang berkualitas. Antenatal yang berkualitas mempunyai tujuan untuk mencegah dan sebagai upaya deteksi dini terjadinya masalah/ komplikasi yang terjadi pada ibu dan janin. Salah satu komplikasi yang dapat dicegah yaitu penularan HIV/AIDS dari ibu hamil HIV/AIDS ke bayi yang dikandung.

Berdasarkan Permenkes RI (2017), diwajibkan melakukan pemeriksaan HIV/AIDS untuk menghindari terjadinya penularan HIV/AIDS dari ibu ke anak yang dilakukan dengan cara pemeriksaan darah pada ibu hamil. Berdasarkan uraian diatas maka peneliti tertarik untuk mengetahui gambaran pemeriksaan HIV/AIDS pada ibu hamil berdasarkan karakteristik di Puskesmas Banjar I Kota Banjar. mencegah HIV/AIDS (Acquired Immune Deficiency Syndrome) dan untuk pengobatannya juga belum ditemukan. Jumlah ibu hamil yang tercatat pada pelayanan PPIA (Pencegahan Penularan dari Ibu ke Anak) adalah sebanyak 15.921 jiwa

\section{Metode}

Penelitian ini merupakan penelitian deskriptif kuantitatif dengan rancangan cross-sectional yaitu desain penelitian yang mengumpulkan datanya dilakukan pada satu 
JOURNAL OF MIDWIFERY CARE :

VOL. 01 NO. 01, DESEMBER 2020

DOI: $\underline{10.34305 / j m c . v 1 i 1.179}$
Ciptaan disebarluaskan di bawah Lisensi Creative Commons AtribusiNonKomersial-BerbagiSerupa 4.0 Internasional. titik waktu atau at one point in time. Populasi dan sampel dalam penelitian ini adalah seluruh ibu hamil pada tahun 2019 di wilayah kerja Puskesmas Banjar I Kota Banjar sebanyak 243 orang. Pengambilan sampel dilakukan dengan teknik total sampling. Total sampling adalah teknik pengambilan sampel dimana jumlah sampel sama dengan populasi (Sugiyono, 2007). Selanjutnya dalam penelitian ini instrumen penelitian menggunakan lembar checklist berdasarkan buku register dan buku Kesehatan Ibu dan Anak (KIA). Pada penelitian ini juga menggunakan data sekunder. Metode yang digunakan dalam penelitian ini adalah dengan menggunakan data ibu hamil di wilayah Puskesmas Banjar I Kota Banjar pada tahun 2019. Dalam penelitian ini peneliti fokus pada pemeriksaan HIV/AIDS pada ibu hamil berdasarkan karakteristik dan pengumpulan data diperoleh setelah sebelumnya mendapatkan izin dari pihak Puskesmas Banjar I Kota Banjar untuk mengadakan penelitian. Penelitian dilakukan dengan cara meminta data ibu hamil dari puskesmas, kemudian melihat berapa banyak ibu hamil yang melakukan pemeriksaan HIV/AIDS di Puskesmas Banjar I Kota Banjar.

\section{Hasil}

Hasil penelitian yang diperoleh tentang gambaran pemeriksaan HIV/AIDS pada ibu hamil berdasarkan karakteristik di Puskesmas Banjar I Kota Banjar tahun 2019, maka dapat disampaikan data sebagai berikut:

Tabel 1. Distribusi Frekuensi Pemeriksaan HIV/AIDS, Usia, Pendidikan, Pekerjaan, dan Paritas Ibu Hamil di Puskesmas Banjar I Kota Banjar Tahun 2019.

\begin{tabular}{lcc}
\hline \multicolumn{1}{c}{ Variabel } & Frekuensi & Persentase (\%) \\
\hline Pemeriksaan HIV/AIDS & 219 & 90 \\
Dilakukan & 24 & 10 \\
Tidak dilakukan & 243 & 100 \\
Jumlah & & \\
Usia & 221 & 91 \\
Reproduksi Sehat & 22 & 9 \\
Non Reproduksi Sehat & 243 & 100 \\
Jumlah & & \\
Pendidikan & 58 & 24 \\
Rendah & 169 & 70 \\
Menengah & 16 & 6 \\
Tinggi & 243 & 100 \\
Jumlah & & \\
Pekerjaan & 34 & 14 \\
Bekerja & &
\end{tabular}


JOURNAL OF MIDWIFERY CARE :

VOL. 01 NO. 01, DESEMBER 2020

DOI: $\underline{10.34305 / \mathrm{jmc} . \mathrm{V} 1 \mathrm{i1} .179}$
Ciptaan disebarluaskan di bawah Lisensi Creative Commons Atribusi-

NonKomersial-BerbagiSerupa 4.0 Internasional

\begin{tabular}{lcc} 
Tidak Bekerja & 209 & 86 \\
Jumlah & 243 & 100 \\
Paritas & & \\
Primipara & 63 & 26 \\
Multipara & 173 & 71 \\
Grandemultipara & 7 & 3 \\
\hline Jumlah & $\mathbf{2 4 3}$ & $\mathbf{1 0 0}$ \\
\hline
\end{tabular}

Berdasarkan tabel 1 dapat diketahui dari 243 responden sebagian besar dilakukan pemeriksaan HIV/AIDS sebanyak 219 responden $(90 \%)$. Sebagian besar ada pada kelompok usia reproduksi sehat sebanyak 221 responden $(91 \%)$.

Sebagian besar pendidikan menengah sebanyak 169 responden $(70 \%)$

Tabel. 2 Distribusi Pemeriksaan HIV/AIDS Pada Ibu Hamil Berdasarkan Usia di Puskesmas Banjar I Kota Banjar Tahun 2019

\begin{tabular}{lcccccc}
\hline \multirow{2}{*}{ Usia } & \multicolumn{3}{c}{ Pemeriksaan HIV/AIDS } & & \multirow{2}{*}{ Total } \\
\cline { 2 - 6 } & \multicolumn{2}{c}{ Dilakukan } & \multicolumn{2}{c}{ Tidak dilakukan } & & \\
\cline { 2 - 6 } & $\mathbf{F}$ & $\mathbf{( \% )}$ & $\mathbf{f}$ & $\mathbf{( \% )}$ & $\mathbf{N}$ & $(\boldsymbol{\%})$ \\
\hline Reproduksi Sehat & 200 & 90.5 & 21 & 9.5 & 221 & 100 \\
Non Reproduksi Sehat & 20 & 90.9 & 2 & 9.1 & 22 & 100 \\
\hline
\end{tabular}

Berdasarkan tabel 2 dapat 200 responden $(90.5 \%)$ dan dari 22 disimpulkan bahwa dari 221 responden yang berusia reproduksi sehat sebagian besar dilakukan pemeriksaan HIV/AIDS sebanyak responden yang berusia non reproduksi sehat sebagian besar dilakukan pemeriksaan HIV/AIDS sebanyak 20 responden (90.9\%).

Tabel. 3 Distribusi Frekuensi Pemeriksaan HIV/AIDS Pada Ibu Hamil Berdasarkan Pendidikan di Puskesmas Banjar I Kota Banjar Tahun 2019.

\begin{tabular}{lcccccc}
\hline \multirow{2}{*}{ Pendidikan } & \multicolumn{9}{c}{ Pemeriksaan } & \multicolumn{2}{c}{ Total } \\
\cline { 2 - 6 } & \multicolumn{2}{c}{ Dilakukan } & \multicolumn{2}{c}{ Tidak dilakukan } & & $(\boldsymbol{\%})$ \\
\cline { 2 - 6 } & $\mathbf{f}$ & $\mathbf{( \% )}$ & $\mathbf{F}$ & $\mathbf{( \% )}$ & $\mathbf{N}$ & 100 \\
Rendah & 45 & 77.6 & 13 & 22.4 & 58 & 100 \\
Menengah & 161 & 95.2 & 8 & 4.8 & 169 & 100 \\
Tinggi & 16 & 100 & 0 & 0 & 16 & \\
\hline
\end{tabular}


JOURNAL OF MIDWIFERY CARE :

VOL. 01 NO. 01, DESEMBER 2020

DOI: $\underline{10.34305 / \mathrm{jmc} . \mathrm{V} 1 \mathrm{i1} .179}$
Ciptaan disebarluaskan di bawah Lisensi Creative Commons AtribusiNonKomersial-BerbagiSerupa 4.0 Internasional

Berdasarkan tabel 3 dapat pemeriksaan HIV/AIDS sebanyak 45 disimpulkan bahwa dari 169 responden responden $(77.6 \%)$, dan dari 16 responden pendidikan menengah sebagian besar dilakukan pemeriksaan HIV/AIDS sebanyak 161 responden $(95.2 \%)$, dari 58 responden pendidikan tinggi seluruhnya melakukan pemeriksaan HIV/AIDS sebanyak 16 responden $(100 \%)$.

pendidikan rendah sebagian besar dilakukan

Tabel. 4 Distribusi Frekuensi Pemeriksaan HIV/AIDS Pada Ibu Hamil Berdasarkan Pekerjaan di Puskesmas Banjar I Kota Banjar Tahun 2019

\begin{tabular}{|c|c|c|c|c|c|c|}
\hline \multirow{3}{*}{ Pekerjaan } & \multicolumn{4}{|c|}{ Pemeriksaan } & \multicolumn{2}{|c|}{ Total } \\
\hline & \multicolumn{2}{|c|}{ Dilakukan } & \multicolumn{2}{|c|}{ Tidak dilakukan } & \multirow[b]{2}{*}{$\mathbf{N}$} & \multirow[b]{2}{*}{$(\%)$} \\
\hline & f & $(\%)$ & $\mathbf{F}$ & $(\%)$ & & \\
\hline Bekerja & 30 & 88.2 & 4 & 11.8 & 34 & 100 \\
\hline Tidak Bekerja & 190 & 91 & 19 & 9 & 209 & 100 \\
\hline
\end{tabular}

Berdasarkan table 4 dapat responden (91\%) dan dari 34 responden yg disimpulkan bahwa dari 209 responden yang bekerja sebagian besar dilakukan tidak bekerja sebagian besar dilakukan pemeriksaan HIV/AIDS sebanyak 30 pemeriksaan HIV/AIDS sebanyak 190 responden $(88.2 \%)$.

Tabel. 5 Tabel Distribusi Frekuensi Pemeriksaan HIV/AIDS Pada Ibu Hamil Berdasarkan Paritas di Puskesmas Banjar I Kota Banjar Tahun 2019

\begin{tabular}{lccccccc}
\hline & \multicolumn{4}{c}{ Pemeriksaan } & & \multirow{2}{*}{ Total } \\
\cline { 2 - 6 } \multicolumn{1}{c}{ Paritas } & \multicolumn{2}{c}{ Dilakukan } & \multicolumn{2}{c}{ Tidak dilakukan } & & \\
\cline { 2 - 6 } & $\mathbf{f}$ & $\mathbf{( \% )}$ & $\mathbf{f}$ & $\mathbf{( \% )}$ & $\mathbf{N}$ & $(\boldsymbol{\%})$ \\
\hline Primipara & 61 & 96.83 & 2 & 3.17 & 63 & 100 \\
Multipara & 151 & 87.29 & 22 & 12.71 & 173 & 100 \\
Grandemultipara & 7 & 100 & 0 & 0 & 7 & 100 \\
\hline
\end{tabular}

Berdasarkan tabel 5 dapat paritas primipara sebagian besar dilakukan disimpulkan bahwa dari 173 responden pemeriksaan HIV/AIDS sebanyak 61 paritas multipara sebagian besar dilakukan responden $(96.83 \%)$, dan dari 7 responden pemeriksaan HIV/AIDS sebanyak 151 paritas grandemultipara seluruhnya responden $(87.29 \%)$, dari 63 responden 
JOURNAL OF MIDWIFERY CARE :

VOL. 01 NO. 01, DESEMBER 2020

DOI: $10.34305 /$ jmc.v1i1.179
Ciptaan disebarluaskan di bawah Lisensi Creative Commons AtribusiNonKomersial-BerbagiSerupa 4.0 Internasional melakukan pemeriksaan HIV/AIDS sebanyak 7 responden(100\%).

\section{Pembahasan}

Berdasarkan hasil penelitian sebagian besar responden dilakukan pemeriksaan HIV/AIDS sebanyak 90\%, sedangkan $10 \%$ tidak dilakukan pemeriksaan. Hal ini dikarenakan menurut Menteri Kesehatan Nila Djuwinta F. Moeloek pemerintah telah mewajibkan pemeriksaan HIV/AIDS pada ibu hamil sejak tahun 2013. Kegiatan ini menjadi bagian dari program layanan pencegahan penularan HIV/AIDS dari ibu ke anak. Menurut hasil penelitian Herdiani et al., (2020), mengatakan bahwa alasan ibu hamil yang tidak melakukan pemeriksaan HIV/AIDS karena mereka takut dan merasa kehamilannya baik-baik saja sehingga tidak perlu dilakukan pemeriksaan HIV/AIDS. Mereka juga mengatakan takut biayanya mahal dan mereka tidak sanggup untuk membayarnya. Selain itu mereka mengatakan tidak tahu bagaimana prosedur yang dilakukan untuk melakukan pemeriksaan HIV/AIDS apa hanya dilakukan pemeriksaan darah saja dan tempat pemeriksaan yang dilakukan di rumah sakit. Menurut hasil wawancara dengan bidan di Puskesmas Banjar I Kota
Banjar penyebab ibu hamil tidak mau dilakukan pemeriksaan dikarenakan merasa takut karena ketidaktahuan mengenai prosedur yang dilakukan untuk melakukan pemeriksaan HIV/AIDS, dan takut hasilnya positif.

Begitupun dengan usia ibu hamil, berdasarkan hasil penelitian sebagian besar responden usia reproduksi sehat dilakukan pemeriksaan HIV/AIDS sebanyak 90.5\%, sedangkan $\quad 9.5 \%$ tidak dilakukan pemeriksaan HIV/AIDS. Menurut hasil wawancara dengan bidan di Puskesmas Banjar I Kota Banjar mengenai responden yang tidak dilakukan pemeriksaan HIV/AIDS hal ini dikarenakan responden merasa takut hasilnya positif. Sedangkan hasil wawancara dengan 10 responden melalui aplikasi Software Handphone hal ini disebabkan karena responden merasa takut mengenai prosedur pemeriksaannya dan takut mengenai hasil pemeriksaannya. Hasil penelitian yang didapat responden dengan usia reproduksi sehat sebagian besar ada pada kelompok paritas multipara. Sehingga alasan tidak dilakukan pemeriksaan karena merasa tidak perlu dilakukan pemeriksaan sesuai dengan pengalaman kehamilan sebelumnya.

Pada kelompok pendidikan didapatkan hasil penelitian diketahui bahwa 
JOURNAL OF MIDWIFERY CARE :

VOL. 01 NO. 01, DESEMBER 2020

DOI: $10.34305 /$ jmc.v1i1.179
Ciptaan disebarluaskan di bawah

Lisensi Creative Commons Atribusi-

NonKomersial-BerbagiSerupa 4.0

Internasional sebagian besar responden dilakukan pemeriksaan HIV/AIDS pada kelompok pendidikan rendah sebanyak $77.6 \%$, sedangkan $22.4 \%$ tidak dilakukan pemeriksaan HIV/AIDS. Menurut hasil wawancara Menurut hasil wawancara dengan bidan di Puskesmas Banjar I Kota Banjar mengenai responden yang tidak dilakukan pemeriksaan HIV/AIDS hal ini dikarenakan kesadaran dan keinginan seseorang dipengaruhi oleh latar belakangnya seperti usia, pendidikan, lingkungan sosial yang meliputi lingkungan tempat tinggal dan lingkungan pekerjaannya. Demikian juga halnya dengan pengetahuan dan kesadaran seseorang terhadap pemeriksaan HIV/AIDS, diperoleh pula melalui proses belajar. Hal ini disebabkan karena semakin tinggi pendidikan maka akan semakin bertambah pula pemahaman mengenai informasi dan pentingnya kesehatan. Sedangkan hasil wawancara dengan 10 responden melalui aplikasi Software Handphone hal ini disebabkan karena responden merasa awam terhadap pemeriksaan, dan responden sulit untuk memahami setiap informasi yang diberikan.

Hasil penelitian yang didapat responden dengan pendidikan rendah sebagian besar mempunyai masalah dengan ekonomi, dan untuk melanjutkan pendidikannya terhambat, dengan begitu nikah di usia muda merupakan solusi yang tepat. Sehingga dengan pendidikan yang rendah menjadi pemicu bagi responden untuk mengalami keterlambatan dalam berpikir dan menerima informasi salah satunya pada saat penyuluhan.

Pada ibu hamil yang bekerja dengan hasil penelitian bahwa pada kelompok bekerja sebagian besar responden dilakukan pemeriksaan HIV/AIDS sebanyak $88.2 \%$, sedangkan $11.8 \%$ tidak dilakukan pemeriksaan HIV/AIDS. Menurut hasil wawancara dengan bidan di Puskesmas Banjar I Kota Banjar mengenai responden yang tidak dilakukan pemeriksaan HIV/AIDS hal ini disebabkan karena responden yang bekerja tidak mempunyai waktu luang untuk menghadiri setiap penyuluhan di posyandu dan memanfaatkan waktu santai dirumah hanya untuk istirahat, bukan untuk mengakses informasi kesehatan melalui media massa. Sedangkan hasil wawancara dengan 10 responden melalui aplikasi Software Handphone hal ini disebabkan karena waktu luang setelah usai bekerja hanya digunakan untuk istirahat dan merasa bahwa tidak perlu melakukan pemeriksaan HIV/AIDS karena sibuk 
JOURNAL OF MIDWIFERY CARE :

VOL. 01 NO. 01, DESEMBER 2020

DOI: $\underline{10.34305 / j m c . v 111.179}$
Ciptaan disebarluaskan di bawah

Lisensi Creative Commons Atribusi-

NonKomersial-BerbagiSerupa 4.0

Internasional bekerja dan tidak pernah bergonta ganti pasangan.

Hasil penelitian yang didapatkan pada kelompok pekerjaan bahwa sebagian besar responden bekerja ada pada kelompok paritas multipara, sehingga alasan tidak dilakukan pemeriksaan HIV/AIDS karena melihat dari pengalaman kehamilan sebelumnya merasa tidak terjadi apa-apa bila tidak diperiksa.

Begitupun dengan kelompok paritas, berdasarkan hasil penelitian diketahui bahwa sebagian besar responden dilakukan pemeriksaan HIV/AIDS pada kelompok paritas multipara sebanyak 87.29\%, sedangkan $12.71 \%$ tidak dilakukan pemeriksaan HIV/AIDS. Menurut hasil wawancara dengan bidan di Puskesmas Banjar I Kota Banjar mengenai responden yang tidak dilakukan pemeriksaan HIV/AIDS hal ini disebabkan karena responden tidak mempunyai pengalaman dari kehamilan sebelumnya sehingga merasa takut bila dilakukan pemeriksaan. Sedangkan hasil wawancara dengan 10 responden melalui aplikasi Software Handphone hal ini disebabkan karena responden merasa tidak perlu dilakukan pemeriksaan HIV/AIDS dikarenakan pengalaman dari kehamilan sebelumnya juga tidak diperiksa, dan merasa takut akan hasilnya, serta tidak ada izin dari suami.

Hasil penelitian yang didapat responden dengan paritas multipara sebagian besar berusia reproduksi sehat, sehingga tidak dilakukan pemeriksaan HIV/AIDS dikarenakan rasa takut akan hasilnya dan tidak ada izin dari suami yang menjadi alasan utamanya.

\section{Kesimpulan}

Ibu hamil sebagian besar tidak dilakukan pemeriksaan HIV/AIDS sebanyak 10\%. Sebagian besar kelompok usia reproduksi sehat tidak dilakukan pemeriksaan HIV/AIDS sebanyak 9.5\%. Sebagian besar tidak dilakukan pemeriksaan HIV/AIDS pada kelompok pendidikan rendah sebanyak $22.4 \%$. Sebagian besar kelompok pekerjaan bekerja tidak dilakukan pemeriksaan HIV/AIDS sebanyak 11.8\%. Sebagian besar tidak dilakukan pemeriksaan HIV/AIDS pada kelompok paritas multipara sebanyak $12.71 \%$.

\section{Saran}

Bidan diharapkan agar meningkatkan kunjungan rumah khususnya pada ibu hamil yang tidak melakukan pemeriksaan HIV/AIDS dan mengarahkan kader-kader untuk mengajak ibu hamil agar mau dilakukan pemeriksaan HIV/AIDS. 
JOURNAL OF MIDWIFERY CARE :

VOL. 01 NO. 01, DESEMBER 2020

DOI: $\underline{10.34305 / j m c . v 1 i 1.179}$

\section{Daftar Pustaka}

Dinas Kesehatan Jawa Barat. (2017). Profil Kesehatan Tahun 2017. Dinas Kesehatan Provinsi Jawa Barat.

Herdiani, T. N., Oktarina, M., \& Herawati, E. (2020). Hubungan Pengetahuan dan Sikap dengan Pemeriksaan HIV pada Ibu Hamil di Puskesmas Argamakmur Kabupaten Bengkulu Utar. Ovary Midwifery Journal, 1(2), 41-51.

Permenkes/Menkes/52/2017, K. K. R. (2017). Tentang Eliminasi Penularan Human Immunodeficiency Virus, Sifilis, dan Hepatitis B dari Ibu ke Anak. Jakarta: Kementerian Kesehatan RI.

Ditjen PP dan PL Kemenkes RI. (2017).
Ciptaan disebarluaskan di bawah Lisensi Creative Commons Atribusi-

Statistik Kasus HIV/AIDS di Indonesia. Direktorat Jenderal Pengendalian Penyakit dan Penyehatan Lingkungan Kementerian Kesehatan Republik Indonesia.

Sugiyono. (2007). Metode Penelitian Kuantitatif Kualitatif dan R\&D. Bandung : Alfabeta.

UNAIDS. (2016). Global AIDS Update. Joint United Nations Programme on HIV/AIDS.

WHO. (2015). World Health Statistics. World Health Organization.

WHO. (2017). Data and Statisticts. 